\title{
Pengaruh Senam Nifas terhadap Penurunan Tinggi Fundus Uteri pada Ibu Post Partum di RSUP DR. M. Djamil Padang
}

\author{
Nurniati Tianastia Rullynil ${ }^{1}$, Ermawati ${ }^{2}$ Lisma Evareny $^{3}$
}

\begin{abstract}
Abstrak
Perdarahan merupakan penyebab utama kesakitan dan kematian ibu pada masa nifas, dimana 50\%-60\% karena kegagalan miometrium berkontraksi secara sempurna. Salah satu asuhan untuk memaksimalkan kontraksi uterus pada masa nifas adalah dengan melaksanakan senam nifas, guna mempercepat proses involusi uteri. Tujuan penelitian ini adalah untuk mengetahui pengaruh senam nifas terhadap penurunan tinggi fundus uteri (TFU) pada ibu post partum. Penelitian ini merupakan studi eksperimental dengan Post Test Only Control Group Design. Alat yang digunakan dalam penelitian berupa kaliper pelvimetri. Diberikan perlakuan senam nifas pada kelompok intervensi dan tidak senam nifas pada kelompok kontrol, kemudian dilakukan pengukuran tinggi fundus uteri hari ke-1, hari ke-3 dan hari ke-6. Data dianalisa menggunakan Uji General Linier Model (GLM). Rerata TFU hari ke-1 pada kelompok intervensi 12,37 $\pm 0,72$ dan 12,42 $\pm 0,54$ pada kelompok kontrol. Rerata TFU hari ke-3 pada kelompok intervensi $9,00 \pm 0,94$ dan $9,87 \pm 0,75$ pada kelompok kontrol. Sedangkan rerata TFU hari ke-6 pada kelompok intervensi $5,72 \pm 0,88$ dan $7,37 \pm 0,68$ pada kelompok kontrol. Terdapat perbedaan yang signifikan penurunan tinggi fundus uteri antara kedua kelompok pada hari ke-3 $(p=0,00)$ dan hari ke $6(p=0,00)$. Dari hasil penelitian dapat disimpulkan bahwa senam nifas berpengaruh terhadap penurunan tinggi fundus uteri. Penurunan tinggi fundus uteri pada kelompok intervensi lebih turun dibanding kelompok kontrol.
\end{abstract}

Kata kunci: senam nifas, tinggi fundus uteri, post partum

Abstract

Hemorrhage is a major cause of maternal morbidity and mortality in the puerperium, about $50 \%-60 \%$ of hemorrhage occurs due to failure of myometrium to contract completely. One care to maximaze uterine contraction during the puerperium is by implementing parturition gymnastics in order to accelarate the process of uterine involution. The purpose of this study was to determine the effect of parturition gymnastics on a decreasing of fundal height of maternal postpartum. This was experimental study with Post Test Only Control Group Design. The tool used in this study was pelvimetry caliper. Parturition gymnastics was given to intervention group but the control group did not treated with parturition gymnastics, then fundal height was measured on the first day, third day, and sixth day. Data were analyzed by using General Linear Model (GLM) test. Mean of fundal height on the first day on the intervention group was $12.37 \pm 0.72$ and $12.42 \pm 0.54$ on the control group. Mean of fundal height on the third day was $9.00 \pm 0.94$ on the intervention group and $9.87 \pm 0.75$ on the control group. Meanwhile, mean of fundal height on the sixth day on the intervention group was $5.72 \pm 0.88$ and $7.37 \pm 0.68$ on the control group. There was significant decrease of fundal height between the two groups on the third day 3 at $(p=0.00)$ and the sixth day at $(p=0.00)$. From the research results, it can be concluded that parturition gymnastic has an effect on the decreasing of fundal height. The decline of fundal height on the intervention group is more decreasing than that of on the control group.

Keywords: parturition gymnastics, fundal height, postpartum

Affiliasi penulis : 1. Prodi Magister Kebidanan Fakultas Kedokteran Universitas Andalas Padang, 2. Bagian Kebidanan FK UNAND /
RSUP Dr. M. Djamil Padang, 3. Prodi Kebidanan Poltekkes Kemenkes Padang 
Korespondensi : Nurniati Tianastia Rullyni, email: nurniatitr@yahoo.co.id, Telp: 081364388817

\section{PENDAHULUAN}

Penyebab terbanyak perdarahan setelah persalinan 50\% - 60\% karena kelemahan atau tidak adanya kontraksi uterus. Kegagalan miometrium berkontraksi secara sempurna akan menimbulkan gangguan serius sehingga terjadi perdarahan hebat setelah melahirkan. Untuk itu penting dilakukannya pelayanan nifas bagi ibu sebagai salah satu pilar utama dalam startegi penurunan Angka Kematian Ibu(AKI). ${ }^{1-3}$

Masa nifas adalah masa setelah plasenta lahir dan berakhir ketika alat-alat kandungan kembali seperti keadaan sebelum hamil. Proses pemulihan kesehatan pada masa nifas merupakan hal yang sangat penting bagi ibu setelah melahirkan, sebab selama masa kehamilan dan persalinan terjadi perubahan fisik, terutama organ reproduksi. ${ }^{4.5}$

Upaya Departemen Kesehatan (Depkes) untuk mempercepat penurunan $\mathrm{AKI}$ adalah dengan mendekatkan pelayanan kebidanan pada setiap ibu, sehingga diharapkan setiap ibu mendapat akses terhadap pelayanan kebidanan. Untuk itu penting adanya standar pelayanan kebidanan dalam meningkatkan kualitas pelayanan kebidanan, termasuk standar pelayanan nifas meliputi pelaksanaan, pemeliharaan dan peningkatan kualitas pelayanan. Bidan memberikan pelayanan selama nifas melalui kunjungan rumah pada 24 jam pertama, hari ke-3, hari ke-6, minggu ke-2 dan minggu ke-6 setelah persalinan untuk membantu proses pemulihan ibu. ${ }^{6.7}$

Bidan diharapkan dapat memberikan asuhan dan pelayanan kebidanan selama periode post partum, mencakup pemenuhan kebutuhan ibu selama masa nifas, untuk itu penting pengembangan standar pelayanan kebidanan untuk meningkatkan kualitas pelayanan kebidanan. Berdasarkan perubahan fisiologi selama kehamilan, maka perlu dilaksanakan latihan selama post partum dengan latihan rutin dan bertahap sesuai kemampuan fisik, sebagai bentuk upaya preventif dan promotif. $^{8.9}$

Masa nifas merupakan proses fisiologis, sehingga bagaimana upaya yang dilakukan supaya kondisi yang fisiologis tidak jatuh ke keadaan patologis adalah dengan memberikan asuhan kebidanan ke- pada ibu nifas. ${ }^{6.7}$

Proses pemulihan organ reproduksi pada masa nifas merupakan hal yang sangat penting. Hal inilah yang mendasari kebutuhan untuk melakukan observasi Tinggi Fundus Uteri (TFU) dan derajat kontraksi uterus. Uterus yang berkontraksi dengan baik secara bertahap akan berkurang ukurannya, sampai tidak dapat dipalpasi lagi diatas simpisis pubis. Kondisi ini tentunya tidak terlepas dari perubahan fisiologi yang luar biasa terjadi selama kehamilan. ${ }^{10-13}$ Diantara faktor yang berperan dalam kontraksi uterus adalah kadar $\mathrm{Hb}$, kadar kalsium, volume intauterin, menyusui dan senam nifas. Senam nifas sebagai salah satu upaya untuk meningkatkan kontraksi uterus masa post partum, maka ibu post partum didorong untuk melakukan senam nifas dalam rangka mempercepat proses involusi uterus. ${ }^{4.5 .17}$

Asuhan essensial diperlukan pada ibu post partum agar dapat mengoptimalkan kontraksi uterus dalam membantu proses involusi uteri, salah satunya dengan melaksanakan senam nifas.

Senam nifas merupakan aktifitas atau latihan peregangan otot yang dilakukan setelah melahirkan meliputi ambulasi dini dan latihan fisik yang dimulai dari latihan yang sederhana dilanjutkan dengan latihan yang lebih berat. ${ }^{4.14}$

Tujuan penelitian ini adalah untuk mengetahui pengaruh senam nifas terhadap penurunan tinggi fundus uteri pada ibu post partum.

\section{METODE}

Penelitian ini merupakan penelitian eksperimental dengan menggunakan Post Test Only Control Group design untuk mengetahui pengaruh perlakuan pada kelompok intervensi dengan cara membandingkan dengan kelompok kontrol. Tempat penelitian adalah di ruang nifas RSUP Dr. M. Djamil Padang. Waktu penelitian dilakukan dari September 2013 sampai dengan April 2014.

Populasi penelitian ini adalah semua ibu post partum spontan yang dirawat di ruang nifas RSUP Dr. M. Djamil Padang. Subjek penelitian yang dipilih adalah semua populasi yang memenuhi kriteria inklusi dan eksklusi. Kriteria inklusi dalam penelitian ini adalah ibu post partum spontan, bertempat tinggal di kota Padang dan bersedia menjadi subjek penelitian. 
Kriteria eksklusi adalah ibu post partum spontan dengan komplikasi dan ibu post partum spontan yang berencana ke luar kota Padang.

Jumlah sampel dihitung dengan menggunakan rumus uji hipotesis terhadap rerata dua populasi independen. ${ }^{15}$ Simpang baku kedua kelompok adalah 0,38 . Berdasarkan rumus tersebut, diperoleh jumlah sampel sebesar 17 orang, ditambah drop outb15\% menjadi 20 orang.

$$
n 1=n 2=2\left\{\frac{(Z \alpha+Z \beta) S^{2}}{\left(X_{1}-X_{2}\right)}\right\}^{2}
$$

Keterangan :

$\mathrm{n}$ = jumlah sampel untuk kelompok perlakuan dan kontrol

$\mathrm{x}_{1}-\mathrm{X}_{2}=$ perbedaan klinis yang diinginkan 0,5

$Z_{\alpha}=$ tingkat kemaknaan $\left(\alpha=5 \% \quad Z_{\alpha}=1,96\right)$

$Z_{\beta}=$ power penelitian $\left(\beta=20 \% \quad Z_{\beta}=0,84\right)$

$\mathrm{S}=0,38^{16}$

Tinggi fundus uteri diukur menggunakan alat kaliper pelvimetri. Alat telah ditera oleh Dinas Perindustrian dan Perdagangan Provinsi Sumatera Barat.

Pengukuran yang dilakukan adalah pengukuran tinggi fundus uteri ibu post partum hari ke1, hari ke-3 dan hari ke-6 pada kelompok yang melakukan senam nifas dan kelompok yang tidak melakukan senam nifas.

\section{HASIL}

Penelitian telah dilakukan terhadap 40 responden yang memenuhi kriteria inklusi dan ekslusi yang terdiri dari dua kelompok (kelompok $A$ sebanyak 20 responden dan kelompok B sebanyak 20 responden). Kelompok A merupakan kelompok yang diberikan perlakuan dengan melaksanakan senam nifas dan kelompok B merupakan responden yang tidak diberikan perlakuan senam nifas.
Tabel1. Karakteristik Responden pada Kelompok Intervensi dan Kelompok Kontrol

\begin{tabular}{lccc}
\hline Karakteristik & $\begin{array}{c}\text { Intervensi } \\
(\mathbf{n = 2 0})\end{array}$ & $\begin{array}{c}\text { Kontrol } \\
(\mathbf{n = 2 0 )}\end{array}$ & $\boldsymbol{p}$ \\
\cline { 2 - 3 } & Mean \pm SD & Mean \pm SD & \\
\hline Usia & $28,90 \pm 4,98$ & $30,75 \pm 4,25$ & 0,21 \\
Paritas & $1,90 \pm 1,02$ & $2,55 \pm 1,19$ & 0,07 \\
IMD & $50 \%$ & $50 \%$ & \\
\hline
\end{tabular}

Berdasarkan tabel 1 dapat dilihat bahwa karakteristik responden pada kelompok intervensi menurut usia didapatkan rerata usia responden adalah 28,90 tahun dengan standar deviasi 4,98, sedangkan rata rata usia responden pada kelompok kontrol adalah 30,75 tahun dengan standar deviasi 4,25. Sedangkan berdasarkan paritas, didapatkan rata-rata paritas pada kelompok intervensi adalah 1,90 dengan standar deviasi 1,02. Rerata paritas pada kelompok kontrol adalah 2,55 dengan standar deviasi 1,19. Untuk kedua kelompok semuanya melaksanakan inisiasi menyusui dini.

Perbedaan rerata karakteristik kedua kelompok responden dengan distribusi normal maka berdasarkan hasil uji statistik dengan uji beda rerata menunjukan bahwa usiadan paritas kedua kelompok responden didapatkan nilai $p>0,05$ artinya tidak terdapat perbedaan rerata usia dan paritas antara kelompok yang diberikan perlakuan senam nifas dengan kelompok kontrol,begitu juga dengan inisiasi menyusui dini (IMD), sama pada kedua kelompok.

Tabel 2. Penurunan Tinggi Fundus Uteri pada Hari ke1, Hari ke-3 dan Hari ke-6 pada Kelompok Kontrol dan Kelompok intervensi

\begin{tabular}{cccccc}
\hline \multicolumn{1}{c}{ KIpk } & TFU 1 & TFU 3 & $\begin{array}{c}\text { Penurunan } \\
\text { TFU }\end{array}$ & TFU 6 & $\begin{array}{c}\text { Penurunan } \\
\text { TFU }\end{array}$ \\
\hline & Mean \pm SD & Mean \pm SD & TFU 1-TFU 3 & Mean \pm SD & TFU 1-TFU 6 \\
\hline Kontrol & $12,42 \pm 0,54$ & $9,87 \pm 0,75$ & 2,55 & $7,37 \pm 0,68$ & 5,05 \\
Intervensi & $12,37 \pm 0,72$ & $9,00 \pm 0,94$ & 3,37 & $5,72 \pm 0,88$ & 6,65 \\
\hline
\end{tabular}

Tabel 2 menunjukkan penurunan rata-rata tinggi fundus uteri pada kelompok kontrol yaitu dari 
$12,42 \mathrm{~cm}$ dengan standar deviasi 0,54 pada pengukuran TFU hari ke-1 menjadi $9,87 \mathrm{~cm}$ dengan standar deviasi 0,75 pada pengukuran TFU hari ke-3 dan $7,37 \mathrm{~cm}$ dengan standar deviasi 0,68 pada pengukuran TFU hari ke-6. Penurunan TFU hari ke-1 dengan TFU hari ke-3 didapatkan penurunan $2,55 \mathrm{~cm}$ dan penurunan TFU hari 1 dengan TFU hari ke- 6 didapatkan penurunan $5,05 \mathrm{~cm}$

Penurunan rata-rata tinggi fundus uteri pada kelompok Intervensi yaitu dari $12,37 \mathrm{~cm}$ dengan standar deviasi 0,72 pada pengukuran TFU hari ke-1, menjadi $9,00 \mathrm{~cm}$ dengan standar deviasi 0,94 pada pengukuran TFU hari ke-3 dan $5,72 \mathrm{~cm}$ dengan standar deviasi 0,88 pada pengukuran TFU hari ke-6. Penurunan TFU hari 1 dengan TFU hari ke-3 didapatkan penurunan $3,37 \mathrm{~cm}$ dan penurunan TFU hari 1 dengan TFU hari ke-6 didapatkan penurunan $6,65 \mathrm{~cm}$.

Tabel 3. Perbedaan Rerata Penurunan Tinggi Fundus Uteri pada Hari 1, Hari ke-3 dan Hari ke-6 Post Partum pada Kelompok Intervensi dan Kelompok Kontrol

\begin{tabular}{lcccc}
\hline Variabel & $\begin{array}{c}\text { Intervensi } \\
(\mathbf{n = 2 0})\end{array}$ & $\begin{array}{c}\text { Kontrol } \\
(\mathbf{n}=\mathbf{2 0})\end{array}$ & $\begin{array}{c}\text { Perbedaan } \\
\text { Penurunan } \\
\text { TFU }\end{array}$ & $\boldsymbol{p}$ \\
\cline { 2 - 4 } & Mean \pm SD & Mean \pm SD & & \\
\hline TFU 1 & $12,37 \pm 0,72$ & $12,42 \pm 0,54$ & 0,05 & 0,80 \\
TFU 3 & $9,00 \pm 0,94$ & $9,87 \pm 0,75$ & 0,87 & 0,00 \\
TFU 6 & $5,72 \pm 0,88$ & $7,37 \pm 0,68$ & 1,65 & 0,00 \\
\hline
\end{tabular}

Tabel 3 menunjukan penurunan rerata tinggi fundus uteri pada hari ke-1 pada kelompok intervensi adalah $12,3 \mathrm{~cm}$ dengan standar deviasi $0,72 \mathrm{~cm}$, sedangkan rerata tinggi fundus uteri hari 1 pada kelompok kontrol adalah 12,42 cm dengan standar deviasi $0,54 \mathrm{~cm}$. Pengukuran tinggi fundus uteri hari 1 antara kelompok intervensi dan kelompok kontrol terdapat perbedaan $0,05 \mathrm{~cm}$. Hasil uji statistik didapatkan nilai $p=0,80$ berarti pada alpha $5 \%$ terlihat tidak ada perbedaan yang signifikan rerata tinggi fundus uteri antara kelompok intervensi dan kelompok kontrol.

Rerata tinggi fundus uteri pada hari ke-3 pada kelompok intervensi adalah $9,00 \mathrm{~cm}$ dengan standar deviasi $0,94 \mathrm{~cm}$, sedangkan rerata tinggi fundus uteri hari ke-3 pada kelompok kontrol adalah $9,87 \mathrm{~cm}$ dengan standar deviasi $0,75 \mathrm{~cm}$. Pengukuran tinggi fundus uteri hari ke-3 antara kelompok intervensi dan kelompok kontrol terdapat perbedaan $0,87 \mathrm{~cm}$.
Hasil uji statistik didapatkan nilai $p=0,00$ berarti pada alpha $5 \%$ terlihat ada perbedaan yang signifikan rerata tinggi fundus uteri antara kelompok intervensi dan kelompok kontrol.

Rerata tinggi fundus uteri pada hari ke-6 pada kelompok intervensi adalah $5,72 \mathrm{~cm}$ dengan standar deviasi $0,88 \mathrm{~cm}$, sedangkan rerata tinggi fundus uteri hari ke- 6 pada kelompok kontrol adalah $7,37 \mathrm{~cm}$ dengan standar deviasi $0,68 \mathrm{~cm}$. Pengukuran tinggi fundus uteri hari ke- 6 antara kelompok intervensi dan kelompok kontrol terdapat perbedaan $1,65 \mathrm{~cm}$. Hasil uji statistik didapatkan nilai $p=0,00$ berarti pada alpha $5 \%$ terlihat ada perbedaan yang signifikan ratarata tinggi fundus uteri antara kelompok intervensi dan kelompok kontrol.

Pada kelompok intervensi maupun kelompok kontrol terjadi penurunan tinggi fundus uteri pada hari ke-1, hari ke-3 dan hari ke-6, namun terlihat penurunan rerata tinggi fundus uteri lebih turun pada kelompok intervensi dibandingkan kelompok kontrol. Perbedaan tersebut dapat dilihat pada gambar berikut ini.

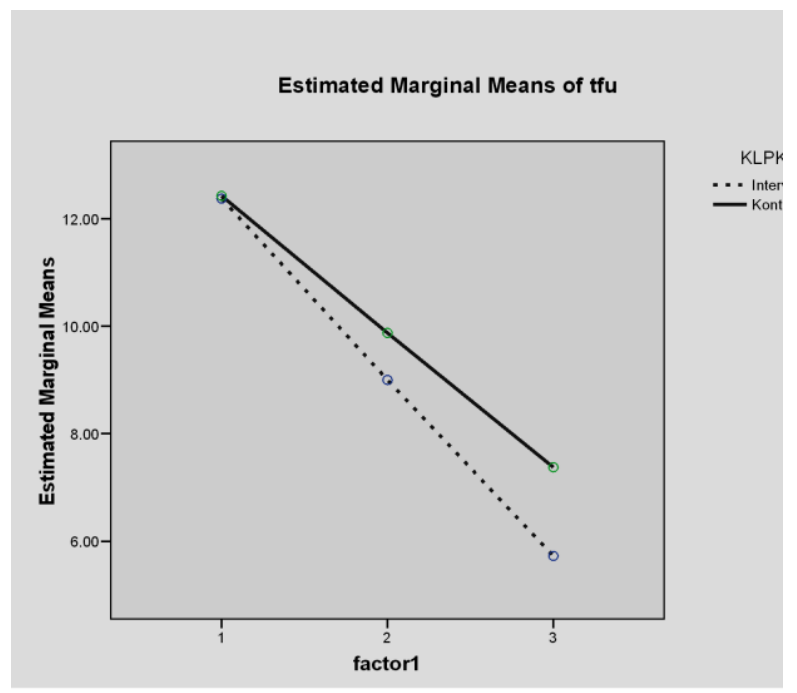

Gambar .1 General Linier Model

Hasil penelitian pada gambar 1 dengan menggunakan uji statistik General Linier Model terlihat ada perbedaan penurunan tinggi fundus uteri ibu post partum pada kelompok intervensi dan kelompok kontrol sesuai dengan intervensi dan jangka waktu intervensi.

Karakteristik responden dari kedua kelompok menunjukkan tidak ada perbedaan baik dari segi 
usia, paritas maupun IMD dengan $p>0,05$. Karakteristik responden baik kelompok intervensi maupun kelompok kontrol sudah homogen, dengan demikian variasi usia, paritas dan IMD tidak mempengaruhi proses involusi uterus.

Rerata tinggi fundus uteri antara kelompok intervensi dan kelompok kontrol terjadi penurunan. Hal ini terjadi diduga terjadi proses involusi uterus yaitu adanya perubahan retrogresif pada uterus yang menyebabkan berkurangnya ukuran uterus. ${ }^{4.5}$ Segera setelah pengeluaran plasenta terjadi kontraksi uterus, sehingga ukuran masing-masing sel menurun secara bermakna yaitu 50-90 $\mu \mathrm{m}$ kali 2,5-5 $\mu \mathrm{m}$ masa post partum. Segera setelah pengeluaran plasenta tinggi fundus uteri menjadi 2 jari dibawah pusat, pada hari ke-5 post partum uterus kurang lebih setinggi $7 \mathrm{~cm}$ atas simpisis atau setengah simpisis pusat. Terjadinya perubahan miometrium yang bersifat proteolisis, reorganisasi dan eksofiliasi tempat perlengketan plasenta yang ditandai dengan penurunan ukuran dan berat uterus. ${ }^{5.17}$

Berdasarkan hasil pengukuran tinggi fundus uteri pada kelompok intervensi maupun pada kelompok kontrol, terlihat pada pengukuran tinggi fundus uteri hari ke-1 dengan pengukuran tinggi fundus uteri hari ke-3 pada kelompok kontrol terdapat perbedaan penurunan tinggi fundus uteri sebanyak $2,55 \mathrm{~cm}$ dibandingkan dengan penurunan tinggi fundus uteri hari 1 dengan pengukuran tinggi fundus uteri hari ke-6 terdapat perbedaan penurunan tinggi fundus uteri sebanyak $5,05 \mathrm{~cm}$. Keadaan ini menggambarkan bahwa semakin bertambah hari post partum semakin turun TFU. Hal ini terjadi oleh karena setelah melahirkan, uterus akan kembali ke keadaan sebelum hamil disebut dengan involusi. Proses ini ditandai segera setelah plasenta keluar akibat kontraksi otot polos uterus. ${ }^{4.5}$

Pada periode post partum, penurunan kadar hormon estrogen dan progesteron menyebabkan terjadinya autolisis yaitu perusakan secara langsung jaringan hipertrofi yang berlebihan. Perubahan lain yang terjadi pada uterus adalah intensitas kontraksi uterus meningkat secara bermakna segera setelah bayi lahir, diduga terjadi sebagai respon terhadap penurunan volume intrauterin. Hormon oksitoksin yang dilepas dari kelenjer hipofisis memperkuat dan mengatur kontraksi uterus, mengompresi pembuluh darah dan membantu hemostasis. Hal inilah yang mendasari terjadinya involusi uterus pada ibu post partum, yang dapat dinilai dengan penurunan tinggi fundus uteri. Fundus turun kira-kira $1 \mathrm{~cm}$ sampai $2 \mathrm{~cm}$ setiap 24 jam. ${ }^{4.17}$

Penurunan tinggi fundus uteri pada kelompok intervensi terlihat lebih turun dibanding kelompok kontrol. Ini terlihat pada pengukuran tinggi fundus uteri hari ke-1 dengan pengukuran tinggi fundus uteri hari ke-3 terdapat perbedaan penurunan sebanyak $3,37 \mathrm{~cm}$, sedangkan pengukuran tinggi fundus uteri hari ke-1 dengan pengukuran tinggi fundus uteri hari ke-6 menunjukan perbedaan penurunan tinggi fundus uteri sebanyak 6,65 $\mathrm{cm}$. Artinya penurunan tinggi fundus uteri pada kelompok intervensi lebih banyak dibanding penurunan tinggi fundus uteri pada kelompok kontrol.

Penambahan 1 frekuensi setiap hari pada tiap gerakan senam nifas, juga akan lebih meningkatkan terjadinya kontraksi uterus sehingga membantu proses involusi uterus. Hal ini terlihat dari rata-rata penurunan tinggi fundus uteri pada hari 1 , hari 3 dan hari 6 semakin turun dan semakin menunjukkan perbedaan tinggi fundus uteri pada setiap pengukuran. Dengan dilaksanakannya senam nifas secara teratur sesuai dengan teknik yang diajarkan membantu menguatkan kontraksi otot rahim, mengakibatkan terjadinya ischemia dengan terkompresinya pembuluh darah sehingga aliran darah ke uterus berkurang. Jaringan mengecil diikuti dengan penurunan ukuran uterus. $^{16}$

Menurut Harrison (2000), bahwa perubahan yang luar biasa terjadi selama masa nifas, yang memungkinkan tubuh akan kembali ke keadaan tidak hamil. ${ }^{19}$ Uterus akan mengalami proses involusi yang dapat dinilai melalui tinggi fundus uteri, namun dengan diberikan intervensi berupa senam nifas kepada ibu post partum akan membantu mempercepat proses involusi uterus.

Hasil uji statistik dengan General Linier Model, dari masing masing kelompok baik kelompok inter-vensi maupun kelompok kontrol terjadi penurunan tinggi fundus uteri pada pengukuran hari 
ke-1, hari 3 dan hari 6 . Ada perbedaan bermakna rerata penurunan tinggi fundus uteri antara kelompok intervensi dan kelompok kontrol.

Pengukuran tinggi fundus uteri hari ke-1 walaupun terdapat perbedaan rerata tinggi fundus uteri antara kelompok intervensi dan kelompok kontrol, secara uji statistik tidak menunjukkan perbedaan yang signifikan didapatkan nilai $p=0,80$, berarti tidak ada perbedaan yang signifikan rerata tinggi fundus uteri antara kelompok intervensi dan kelompok kontrol pada hari ke-1, sedangkan pengukuran tinggi fundus uteri pada hari ke-3 juga terdapat perbedaan antara kelompok intervensi dan kelompok kontrol, secara statistik didapatkan nilai $p=0,00$ berarti ada perbedaan yang signifikan rata-rata tinggi fundus uteri antara kelompok intervensi dan kelompok kontrol, begitu juga pada tinggi fundus uteri pada hari ke-6 didapatkan perbedaan tinggi fundus uteri antara kelompok intervensi dan kelompok kontrol, secara statistik didapatkan nilai $p=0,00$ berarti ada perbedaan yang signifikan rerata tinggi fundus uteri antara kelompok intervensi dan kelompok kontrol.

Penelitian ini menunjukkan bahwa terdapat pengaruh yang bermakna pada kelompok intervensi. Hal ini membuktikan teori bahwa pelaksanaan senam nifas pada ibu post partum dapat membantu mempercepat proses involusi uteri yang salah satunya dapat dinilai melalui pengukuran terhadap tinggi fundus uteri ibu post partum. ${ }^{5.20}$

Pelaksanaan latihan fisik (senam nifas) pada ibu post partum, maka sel otot akan terangsang secara kimiawi, listrik dan mekanik untuk membangkitkan potensial aksi yang dihantarkan sepanjang membran sel, dengan adanya potensial aksi maka akan terjadi mekanisme kontraktil oleh protein kontraktil aktin dan miosin, sehingga mengubah energi hasil hidrolisis ATP menjadi gerakan suatu komponen seluler disepanjang komponen lainnya. ${ }^{21.24}$

Peregangan mekanis akan memodifikasi permiabilitas saluran $\mathrm{Ca}^{+}$di membran plasma dan retikulum sarkoplasma, ini membuat ion kalsium masuk ke dalam sel sehingga terjadi kontraksi otot uterus. ${ }^{22.24}$

Latihan fisik (senam nifas) akan menyebabkan terjadinya eksitasi otot, yang akan menyebabkan terjadinya peningkatan kalsium sitosol terutama dari cairan ekstraseluler, selanjutnya akan terjadi serangkaian reaksi biokimia yaitu kolmodulin (protein sel) berikatan dengan kalsium akan mengakibatkan kinase rantai ringan miosin menjadi aktif sehingga jembatan silang miosin terfosforilasi sehingga terjadi pengikatan aktin dan miosin, maka terjadilah kontraksi. ${ }^{23.24}$

Senam nifas sebagai salah satu bentuk latihan fisik, akan memberi dampak terhadap sistem kardiovaskuler, aliran darah otot dan curah jantung meningkat begitu pula pada sistim pernafasan dan sistem metabolik dalam perubahan ATP dan ADP dengan pelepasan energi ke otot untuk berkontraksi. ${ }^{22.24}$

Kontraksi pada uterus akan mempercepat proses involusi uterus yaitu perubahan retrogresif pada uterus yang menyebabkan berkurangnya ukuran uterus. Uterus yang berkontraksi dengan baik secara bertahap akan berkurang ukurannnya, sampai tidak dapat dipalpasi lagi diatas simpisis pubis. ${ }^{5.11}$

Transformasi miometrium ini berhubungan erat dengan aktivitas protein intraseluler yaitu contraction associated proteins pada sel otot polos miometrium yang terdiri dari membrane cell receptors, ionic chanels, gap junction proteins dan contractile proteins. $^{30.34}$

Dasar mekanisme kontraksi uterus adalah perubahan aktivitas elektrik. Perbedaan potensial elek-trik diantara membran plasma (membran potensial) karena distribusi yang tidak sama ion antara intra dan ekstra sel. Kondisi ini terjadi karena biomolekul yang bermuatan negatif intraseluler dalam jumlah besar yang tidak dapat keluar dan kanal membran plasma yang selektif. lon-ion akan bergerak dengan arah yang ditentukan oleh perbedaan konsentrasi dan potensial membran. $^{35}$

Miometrium mengalami perubahan ritmik membran potensial, dengan masuknya $\mathrm{Ca}^{2+}$ melewati membran plasma melalui voltage $\mathrm{Ca}^{+}$channels. Gap junction sebagai kanal intraseluler yang bila terbuka akan menfasilitasi komunikasi elektrik dan metabolik diantara sel miometrium. Fungsi gap junction diregulasi oleh jumlah gap junction dan kecepatan degradasinya. Pada miometrium, gap junction meningkat jumlahnya pada persalinan spontan, namun akan secara cepat menghilang sesudah persalinan sebagai 
akibat dari proses internalisasi, endositosis dan diiringi dengan penurunan eksitabilitas dan kontrakstilitas otot polos miometrium. Peningkatan $\mathrm{Ca}^{2+}$ intraseluler akan memicu kontraksi otot. ${ }^{34.35}$

Myosin otot polos merupakan suatu protein, ketika myosin berinteraksi dengan aktin, aktivitas ATPase pada myosin akan teraktivasi. Energi yang dibangkitkan sebagai hasil hidrolisis dikonversi sebagai energi yang memungkinkan kepala myosin bergerak, kemudian terlepas dan melekat kembali pada sisi yang lain pada filamen aktin bila mengalami reaktivasi. ${ }^{31.33}$

Interaksi aktin dan myosin diregulasi oleh $\mathrm{Ca}^{2+}$. Efek dari kalsium dimediasi oleh suatu $\mathrm{Ca}^{2+}$ dan kolmodulin. Komplek $\mathrm{Ca}^{2+}$ berikatan dengan kolmodulin akan meningkatkan aktivasi MLCK. Selanjutnya MLCK akan memfosforilasi myosin. Fosforilasi myosin berhubungan dengan suatu peningkatan aktivitas ATP-ase dan menfasilitasi interaksi aktin dan myosin. ${ }^{31.32}$

Penelitian ini sejalan dengan penelitian Larson (2002), tentang efek senam nifas pada masa post partum, mengalami pengkerutan pada rahim yang lebih kuat. $^{18}$ Penelitian Azizah pada tahun 2013 , menyatakan bahwa terdapat perbedaan involusi uterus antara kelompok yang melakukan senam nifas dengan kelompok yang tidak melaksanakan senam nifas. Senam nifas akan merangsang kontraksi otot uterus sehingga proses involusi berjalan lebih cepat. Latihan fisik berupa senam nifas dapat menimbulkan rangsangan sehingga meningkatkan aktivasi kimiawi, terjadi peningkatan metabolisme mitokondria untuk menghasilkan ATP sebagai energi untuk kontraksi. ${ }^{26}$

Penelitian Emily (2010); menyatakan bahwa senam nifas sangat efektif dalam meningkatkan kesejahteraan ibu dan dapat mengurangi masalah jangka panjang pada masa nifas. Penelitian ini menggunakan latihan fisik selama 30 menit dilaksanakan 2 kali seminggu dengan kombinasi latihan aerobik memperlihatkan pengaruh yang signifikan pada kelompok yang melaksanakan latihan fisik pada masa pospartum terhadap kesejahteraan ibu. $^{29}$

Bahadoran (2006); menyatakan bahwa senam nifas mempengaruhi aspek fisik guna meningkatkan kualitas hidup ibu post partum. Terdapat pengaruh yang signifikan pada kelompok ibu yang melakukan latihan fisik terhadap kesejahteraan fisik ibu post partum. Latihan fisik teratur merupakan faktor penting untuk menjaga kesehatan fisik juga mempertahan fungsi dan kekuatan otot secara maksimal termasuk organ reproduksi. $^{27}$

Hammer (2000) menyatakan bahwa dengan adanya program latihan selama post partum dapat memperkuat pemulihan otot yang terbebani selama hamil dan persalinan, serta meningkatkan kesehatan dan kebugaran ibu post partum. Kesimpulan dari analisis ini menggambarkan bahwa program latihan yang dilaksanakan masa nifas akan memulihkan hampir seluruh organ tubuh dan proses involusi ini sangat jelas terlihat pada alat-alat kandungan. ${ }^{28}$

Penelitian Surtiati dan Nawati (2010); menyebutkan senam nifas yang dilakukan pada ibu post partum berpengaruh terhadap pemulihan fisik sembilan kali lebih baik pada ibu yang diberi intervensi senam nifas dibandingkan dengan ibu yang tidak diberikan intervensi senam nifas. Latihan fisik berupa senam nifas pada masa post partum berpengaruh terhadap pemulihan fisik ibu post partum lebih cepat. Keterangan ini menandakan bahwa pemulihan fisik termasuk involusi uterus. ${ }^{14}$

\section{KESIMPULAN}

Ada pengaruh senam nifas terhadap penurunan tinggi fundus uteri pada ibu post partum. Penurunan tinggi fundus uteri lebih cepat pada kelompok senam nifas dibandingkan dengan kelompok yang tidak senam nifas, yang sangat bermakna secara statistik.

\section{UCAPAN TERIMA KASIH}

Penulis mengucapkan terima kasih kepada Poltekkes Kemenkes Tanjungpinang atas kesempatan yang diberikan untuk melanjutkan pendidikan. Kepada RSUP Dr. M. Djamil Padang sebagai tempat penelitian atas fasilitas yang telah diberikan. Kepada dr. Ermawati, SpOG(K) dan Lisma Evareny, S.Kep, MPH sebagai pembimbing atas masukan dan bimbingan dalam menyelesaikan tesis ini. 


\section{DAFTAR PUSTAKA}

1. Syaifuddin AB. Buku panduan praktis pelayanan kesehatan maternal dan neonatal. Jakarta: YBP-SP; 2009.

2. Coat J, Melyn D. Anatomi fisiologi untuk bidan (terjemahan). Jakarta: EGC; 2007.

3. Kementerian Kesehatan RI. Kualitas pelayanan kesehatan ibu di Indonesia. Jakarta: Kemenkes RI; 2012.

4. Bobak IM, Lowdermilk D, Jensen M, Perry S. Buku ajar keperawatan maternitas (terjemahan). Jakarta: EGC; 2004.

5. Varney $H$, Kriebs M, Gegor C. Buku ajar asuhan kebidanan (terjemahan). Volume 2. Jakarta: EGC; 2007.

6. Departemen Kesehatan Republik Indonesia. Standar pelayanan kebidanan. Jakarta: Depkes RI; 2005.

7. PP IBI. 50 Tahun ikatan bidan Indonesia bidan menyongsong masa depan. Jakarta: PP IBI; 2004

8. Tapiwa M. An evaluation of the quality of care midwives provide during the postpartum period in Northern Botswana (thesis). Botswana: Institute of General Practise and Community Medicine, The Faculty of Medicine, University Oslo; 2001.

9. Evensen K. Towards an understanding of change in physical activity from pregnancy through postpartum. NIH Public Acces Aouthor Manuscript. Psychal Sport Exerc;12(1):36-45.

10. Anderson B, Torvin L, Sorensen $T$. Metylergometrin during the early puerpureum: a prospective randomised double blind study. Acta Obstetricia et Gynekology Scandinavia;1998: 54-7.

11. Cluet $E R$, Alexander J, Pickering R. What is the normal patern of uterine involution ? an investigation of postpartum involution measured by distance between the symphysis pubis and the uterine fundus using a tape measure midwifery. 1997;13:9-16.

12. Merchant S, Alexande J, Garcia J. How does it feel to you? uterine palpation and lochea loss as guides to postnatal recovery 2- the blipp study. Practising Midwife; 1999.

13. Fraser M D, Cooper M. Myles textbook for midwives. Edisi ke-14. Elsevier; 2004.

14. Surtiati E, Nawati. Pengaruh senam nifas terhadap pemulihan fisik ibu post partum spontan di rumah sakit PMI dan Salak kota Bogor. Bandung: Risbinakes Poltekkes Bandung; 2010.

15. Sastroasmoro S. Dasar-dasar Metodologi Penelitian Klinis. Jakarta: Sagung Seto; 2011.

16. Tambunan $Y$. Pengaruh senam nifas terhadap involusi uterus ibu nifas. Medan: Fakultas Kedokteran Universitas Sumatera Utara; 2009.

17. Cuningham FG, Leveno K, Bloom SL, Hauth C, Rause D, Spong CY. Obstetri Williams (terjemahan). Jakarta: EGC; 2012.

18. Larson M. Effect of postpartum exercise on mothers and their offspring: a review of the literature. Obesity research. 2002;10:841-53.

19. Harrison J. Physiological changes of the puerpureum. British Journal of Midwifery. 2000;8(8):483-8.

20. Brayshaw E. Senam hamil dan nifas pedoman praktis bidan. Jakarta: EGC; 2008.

21. Ganong WF. Buku ajar fisiologi kedokteran. Review of Medical Physiology. Edisi ke-20. Jakarta: EGC; 2002

22. Guyton A, Hall J. Buku ajar fisiologi kedokteran. Jakarta: EGC; 2007.

23. Murray R, Granner DK, Roodwell V. Biokimia Harper. Jakarta: EGC; 2009. hlm. 582-604.

24. Sheerwood. Fisiologi manusia dari sel ke sel. Jakarta: EGC; 2011.

25. Charles A. The reability and validity of fundal height measurement. Eviden based Clinical Practice Guideline. Student Projects; 2001.

26. Azizah. Involution post partum mothers with a history of spontaneus labor complication when i-ii extend maternity room RSD Kalisat (thesis). Jember: Fakultas IImu Kesehatan. Universitas Muhammadiyah; 2013.

27. Bahadoran B, Abbasi F, Yousefi A, Kargarfard M. Evaluating the effect of 
exercise on the postpartum quality of life. Iranian journal of Nursing and Midwifery research (INMR) Winter.2006;12(1).

28. Hammer R, Parkins, Parr R. exercise during the childbearing year. The Journal of Perinatal Education. 2000;9(1).

29. Emily N, Margaret S, Richard H, Mary P. An exercise and education improves well-being of new mothers: a randomized controlled trial. American Physical Therapy Association. 2010; 90(3).

30. Anwer K. Calcium-activated channels as modulators of human myometrial contractile activity. Am J Physiol Cell Physiol.2000;265.

31. Sanbora BM. Hormon and calcium : mechanism controlling uterine smooth muscle contractile activity. The Litchfield Lecture Exp Physiol; 86:223-37.
32. Wray S, Jones K, Matthew A, Noble K, Kupittayanant, Li Y. Calcium signalling and uterine contractility. J Sac Gynecol Investig. 2001; (10): 252-64.

33. Parkington HC, Tonta MA, Coleman HA. contractile activity, membrane potencial and cytoplasmic calcium in human uterine smooth muscle in the third trimester of pregnancy and during labor. Am J Obstet Gynecol; (181): 1445-51.

34. Buxton L. Regulation of uterine function : a biochemical conundrum in the regulation of smooth muscle relaxation. Mol pharmacol. 2004;(65): 1051-59.

35. Cole HA. Changes in the mechanism involved in uterine contraction during pregnancy in guineapigs. J Physial. 2000; (253):785-98. 